RM-77-026

MOBILIZATION AND IMPACTS OF BIO-GAS TECHNOLOGIES

\author{
Jyoti K. Parikh \\ Kirit S. Parikh
}

November 1977

Reprinted from Energy, Vol. 2,pD. 441-455. pergamon Press 1977. 
The Energy program of IIASA is examining the various energy options which will probably contribute to the energy mix in the future. Organic material from farm wastes or from forests constitutes in principle a very large resource which is used very little mainly because it is not well suited to be burned in a well regulated and efficient way. A possible solution could be in fermenting these materials to $\mathrm{CH}_{4}$ (and $\mathrm{CO}_{2}$ ), making them available for gas burners and internal combustion engines.

"Pre-treated" organic materials like cow dung may be specially suitable for this, particularly if the local climate provides a base temperature sufficiently high for the fermentation to proceed rapidly. In this frame the experiments done in India and elsewhere with animal waste fermenters to produce "bio-gas" constitute an interesting test bed for a technique that could in principle provide most of the primary energy for small communities through self-help. 



\title{
MOBILIZATION AND IMPACTS OF BIO-GAS TECHNOLOGIES
}

\author{
JyOTI K. PARIKH and KIRIT S. PARIKH \\ International Institute for Applied Systems Analysis, A-2361 Laxenburg, Austria
}

(Received 23 November 1976)

\begin{abstract}
At present, energy and fertilizer requirements of many of the developing countries are largely met by locally available, non-commercial sources, such as frewood and farm wastes. Extensive use of frewood is one of the factors that can lead to deforestation. When organic farm wastes are burnt, soil nutrients, which should return to soil, are lost and this can severely affect agricultural production. The problem of efficient utilization of these locally available resources, therefore, needs to be studied in a systematic manner. As an option for efficient utilization of local resources, bio-gas plants are considered, taking India as a case study. In these plants, animal dung and agricultural byproducts are utilized to obtain both methane and fertilizer through anaerobic fermentation. This is an example of appropriate technology for rural environments, which requires low investment, which does not need highly skilled labor and which can be operated with local materials and self-help in the 576,000 villages of India. The economic benefits to a family using a bio-gas plant and the impact of its widespread acceptance on a national scale are evaluated. It is felt, however, that the scope of such individual family bio-gas plants is likely to be limited for a number of reasons. To realize the potential of bio-gas fully, village plants of about $200 \mathrm{~m}^{3}$ capacity for approx. 100 families are needed.

The introduction of such seemingly sensible new technologies has failed in the past for want of appropriate management and organizational structures and, consequently, for want of social participation by persons of various income groups in the successful operation of such community plants. To remedy this, a pricing policy for purchase of farmwastes and distribution of gas and fertilizer has been suggested as an essential tool to ensure that no-one is worse off by the introduction of bio-gas plants and thus to motivate the required participation in the scheme. Given a different organizational set-up, the idea could also be tried out for providing energy and sanitation in urban areas.

The impact of full-scale adoption could mean that, by $2000 \mathrm{AD}$, almost $90 \%$ of the rural energy requirements of the domestic sector could be met; at present, this accounts for about $45 \%$ of the total energy consumption in India. The consequent reduction in firewood consumption would help to prevent deforestation. In addition, organic manure containing two million tons of additional nitrogen would be available every year to enhance soil nutrients, hence boosting food production and helping to solve the problem of sanitation at the same time.
\end{abstract}

\section{INTRODUCTION}

In 1973, the annual consumption of commercial energy in the developing countries was $388 \mathrm{~kg}$ of coal equivalent (kgce) per person, whereas in the case of developed countries it was $6531 \mathrm{kgce}$ per person.' In fact, in most of the developing countries of Asia and Africa, the commercial energy consumption was about $220 \mathrm{kgce}$ per person only. This is not even adequate to cook their minimal meals. The major sources of energy in many developing countries are non-commercial in nature, such as firewood and farm waste. Because of inadequate transport facilities, it is difficult to provide commercial energy in the rural areas where a large fraction of the population lives. Furthermore, the transport costs are so high that, by the time a fuel reaches the rural areas, it is too expensive for purchase. As a result of the rise in oil prices, one more resource has nearly vanished from their purchase list, thus increasing the dependence on locally available resources.

Similarly, chemical fertilizers do not reach the smaller villages in rural areas and, if they do, they are relatively expensive. Thus, the demand for fertilizers also has to be met by local resources. Unfortunately, local resources for fertilizers are the same as the ones used for fuels; for example, animal dung and agricultural waste can be used for composting (for fertilizer) as well as for burning as fuel. Fuel and fertilizer, therefore, compete for the same resources.

The non-commercial sources provide as much as $50 \%$ of the total energy requirements for nearly half of the world, comprising Asia, Africa and Latin America. It is therefore essential that efficient utilization of these resources be studied systematically. It is also necessary to attack the problems of energy and agriculture simultaneously.

†Paper presented at the BMFT-UNITAR Seminar on "Microbial Energy Conversion" at the Institute of Microbiology, Göttingen, FRG, October 1976. 
Two main advantages in favor of utilizing the non-commercial sources in the rural areas are that they are locally available and are, at least in principle, renewable resources.

\section{SOME CONSTRAINTS AND STRATEGIES}

It is generally true that commercial energy sources are convenient to use and are preferred by individuals who can afford them. However, it is not possible to provide commercial energy on a national scale in many developing countries for the following reasons: (a) High capital costs of commercial energy supply. (b) High discount rate because of shortage of capital. (c) Lack of skilled manpower in the rural areas. (d) Decentralized needs of rural areas involving high transmission losses and inadequate demand to justify the setting up of local power plants. (e) High transport costs for fuels such as coal and oil and lack of infrastructure, i.e. inadequate roadways, repair shops, carriers and communication facilities.

The developing countries have many other common features such as high populations, agrarian economies, generally warm climates, etc. Therefore, the strategy, with the constraints imposed by these realities, should be to choose options keeping in mind the following requirements: (a) High output capital ratio or rate of return. (b) Unit size appropriate to small-scale activities. (c) Labor-intensive rather than capital-intensive technology. (d) Self-help technology not requiring highly skilled labor. (e) Use of locally available resources to reduce transport.

Such options, if available, will release energy resources such as kerosene, coal and land devoted to growing firewood.

In the following analysis, we consider initially the possibility of utilizing the farm waste consisting of animal dung and agricultural waste through bio-gas plants taking India as a case study. Later on, we discuss the possibility of extending this idea not only to other developing nations but also to developed countries such as the U.S.

\section{ENERGY SCENE OF INDIA}

The growth of energy consumption in India over the last two decades may be seen in Fig. 1 . The demand for non-commercial sources is still increasing, although as a percentage of total energy it is decreasing. ${ }^{2}$

The demand in the household sector is large and exceeds $75 \%$ of total energy consumption. Though large in percentage terms, it is very low in absolute terms if one compares it to the household sector consumption in any developed country. The percentage is large, because of the large population, the inefficient equipment used for burning domestic fuels and the low level of industrial development. The contribution of non-commercial energy to total energy is nearly $67 \%$.

To assess the magnitude of the tasks involved, it should be noted that approx. $30 \%$ of the 567,000 villages are electrified. ${ }^{3}$ Besides, electricity is not a substitute for domestic fuel in the absence of modern technological devices. Thus, providing commercial energy for domestic purposes in the near future is a formidable task requiring substantial resources of capital, manpower and technological infrastructure.
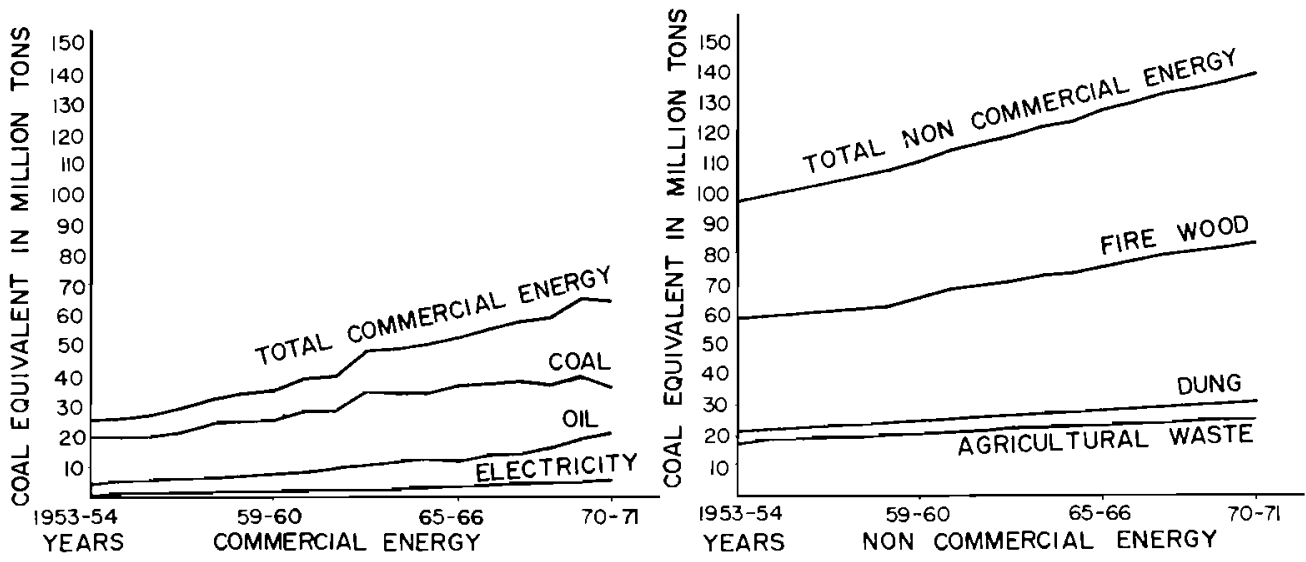

Fig. 1. Growth of energy consumption in India. (For U.N. coal; $1 \mathrm{~kg}=7000 \mathrm{kcal}$ ). 
In view of the facts that (a) India has an agrarian economy, where the cattle-to-people ratio is nearly $1: 2$ in the rural areas, ${ }^{4}$ and (b) there is a large demand for fuel and fertilizers, the possibility of installing bio-gas plants on a large scale needs to be studied in detail. India has the highest cattle population in the world. The number of bovine cattle and buffalo was around $235 \mathrm{M}$ in 1973. This number is far larger than that of Europe and the U.S. which have 130 and $122 \mathrm{M}$ cattle, respectively. In India, bullocks are used for farming, as well as for transport. The animals in India are underfed and output in the form of meat, milk and dung is much less than that in Europe, the U.S. or the world average (see Table 1).

Table 1. Cattle and buffalo population and performance, 1973; Source: FAO Yearbook (1973).

\begin{tabular}{lrrrr}
\hline & India & Europe & U.S. & World \\
\hline Cattle (in millions) & 235 & 130 & 122 & 1275 \\
Yield of milk (kg/yr) & 486 & 3119 & 4631 & 1916 \\
Meat (kg per animal slaughtered) & 110 & 200 & 263 & 185 \\
\hline
\end{tabular}

The rural energy problem is to be viewed against the backdrop of the socio-economic situation in India, where the GNP per capita in 1973 is around $\$ 120$ per yr at market price and the wage rate in rural areas is $\$ 0.50$ per day. An investment of $\$ 200$ for domestic fuel and lighting amounts to six months of income for a family.

In the rural areas, the man-hours spent per week for gathering and tending fuel for family needs are considerable.

The modest import of oil of about $15 \mathrm{M}$ tons per yr claims more than $1 / 3$ of the foreign-exchange earnings of the country.

\section{TECHNOLOGY OF BIO-GAS PLANTS}

In bio-gas plants, organic material mixed with water is allowed to ferment anaerobically (i.e. in the absence of air and oxygen). During fermentation, gas, which is $60 \%$ methane, is generated. The left-over sludge retains its nitrogen. Therefore, both of the useful constituents of farm wastes, namely, hydrocarbons and nitrogen, are appropriately utilized for fuel and fertilizer, respectively. Actually, the utilization efficiency is increased by fermentation. In dried dung, carbon burns with $11 \%$ efficiency in the customary open fire is opposed to $60 \%$ efficiency for methanes obtained from bio-gas plants. Similarly, the digested sludge, which has $1.5-2 \%$ of nitrogen, is a better fertilizer than that obtained through composting of the same dung because composting involves losses and leads to products with only $0.75-1 \% \mathrm{~N}$. A schematic diagram of a bio-gas plant is shown in Fig. 2. The schematic model shows that the organic matter is fed as an input and methane and fertilizers are obtained as outputs.

The plant has two main parts: a digester in which material for fermentation mixed with water is introduced and a gas holder in which the generated gas is collected. The digested sludge comes out at the outlet and is collected in a pit. It is used as a fertilizer, either directly, or is allowed to drain into a drainage pit for later use. The size of the digester depends upon the number of days the material has to be kept in for fermentation and the amount of material fed in every day. Similarly, the size of the gas holder depends on the period over which gas has to be stored.

In the design commonly used in villages in India, where more than 20,000 small family units have been installed over the past $15 \mathrm{yr}$, the digester is just a pit dug in the ground and lined with brick masonry. The gas holder is made of steel and floats over a water seal. The floating gas holder provides a simple way to maintain uniform pressure $(10 \mathrm{~cm}$ of water $)$ of gas. When the gas holder is full of gas and more gas is generated, the excess simply leaks out through the water seal.

The fermentation process is sensitive to pressure, as well as to temperature. Though a uniform pressure is maintained with the floating drum, no attempt is made to maintain uniform temperature in the plants installed in India. Thus, the rate of gas production varies from month to month and is lowest during the winter month of December. In the rather simple, robust and crude plants designed for Indian villages, the winter gas production rate is less than half that of the peak rate obtained in the summer months. These plants are mainly operated on animal 


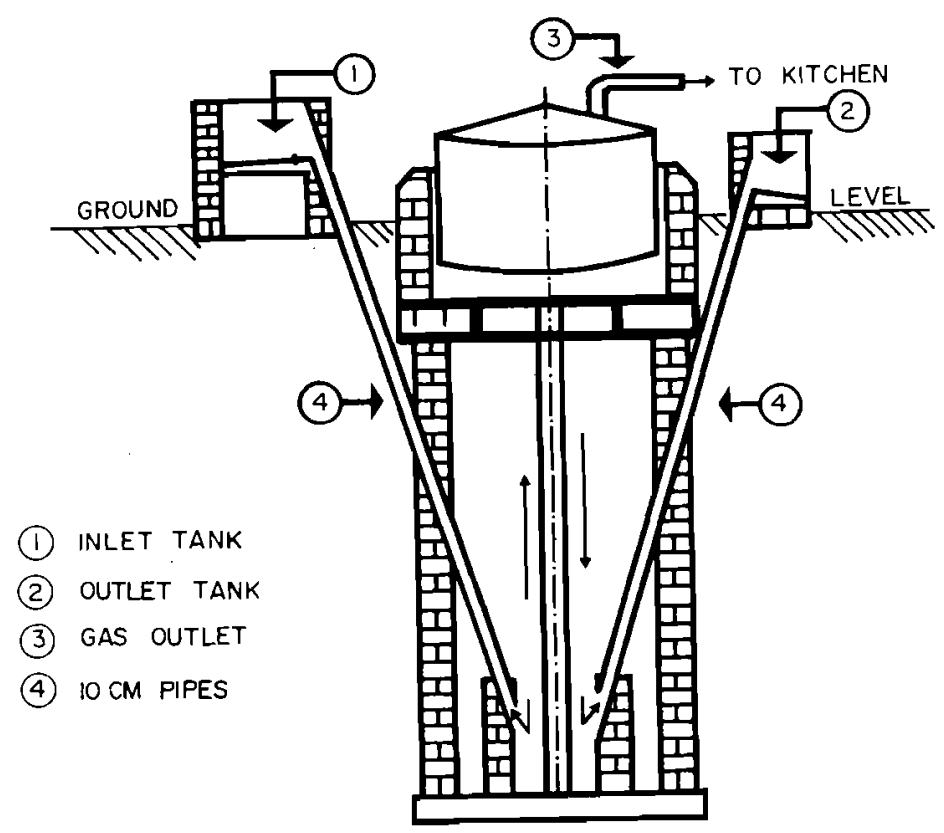

Fig. 2. Schematic diagram of a bio-gas plant.

Table 2. Some relevant data for bio-gas plants.

\begin{tabular}{ll}
\hline Input of dung (dry weight) & $\sim 2.8 \mathrm{~kg} /$ day per buffalo \\
& $\sim 2.0 \mathrm{~kg} / \mathrm{day}$ per cow \\
& $\sim 0.8 \mathrm{~kg} / \mathrm{day}$ per calf \\
& At $15^{\circ} \mathrm{C}, 0.18 \mathrm{~m}^{3}$ of gas $/ \mathrm{kg}$ of dung \\
Production of gas & $4770 \mathrm{kcal} / \mathrm{m}^{3}$ \\
Calorific value of gas & $60 \%$ \\
Burning efficiency & $4770 \times 0.60=2860 \mathrm{kcal} / \mathrm{m}^{3}$ of gas \\
Effective heat obtained & $0.72 \mathrm{~kg}$ of dry sludge with $2.0 \%$ nitrogen $/ \mathrm{kg}$ of dung \\
Production of fertilizer & \\
Gas consumption & $0.34 \mathrm{~m}^{3}$ per person per day \\
for cooking & $0.125 \mathrm{~m}^{3}$ per hour per lamp of 100 candle power \\
for lighting & $0.425 \mathrm{~m}^{3}$ per horse power hour \\
for motive power &
\end{tabular}

dung; most of the technical data given in Table 2 are based on experiments and experience in actual village operations of the Khadi and Village Industries Commission ${ }^{6}$ (of India) which has been in charge of the bio-gas program and has installed more than twenty thousand plants in different parts of India.

Once the plant is installed and attains a steady production state (this takes about 45 days), the operation is relatively simple. To prevent corrosion, the steel gas-holder has to be painted once a year. The present designs of bio-gas plants in India have been developed by creative and practical tinkerers. They have not been engineered by chemical engineers or process technologists. Therefore, considerable scope may exist to streamline the designs of bio-gas plants.

A comprehensive list of major tasks of research and development in promoting bio-gas plants is provided by Prasad $e$ t al. ${ }^{7}$ These authors suggest the various studies which ought to be carried out for techno-economic evaluation in employing various fermentable materials, in fermentation research and technology, for efficient design of plants, to study the gas and fertilizer outputs under various conditions, and in storing, distributing and utilizing bio-gas. Even without potential improvements, the plants function reasonably in the technical environment of rural India. The plants, however, require investment and we now turn to examine the economic viability and the potential of such plants.

\section{SINGLE-FAMILY BIO-GAS PLANTS}

It is necessary to have three to five animals to run a plant for the cooking and lighting requirements of a family. The number of animals required depends on the health and the feed of animals. An investment of Rs. 2000 (\$200) per plant would be required, in addition to a small piece of land in the backyard. 
(a) Economic analysis

A family owning five animals would have at least $10 \mathrm{~kg}$ of dung (dry matter weight) per day, assuming a dung collection rate of $75 \% .^{8}$ This can be beneficially used in three alternative ways; namely, composted to get fertilizer or dried and burnt as fuel or fed into a bio-gas plant to obtain both fertilizer and fuel. If we want to compare the three alternatives, we must evaluate the costs of obtaining (from the same quantity of dung) equal amounts of fuel and fertilizer from each one (of the three alternatives), adding in supplementary purchases from the market where necessary. Thus, to get an amount of fuel and fertilizer equal to that obtained from a bio-gas plant, the family which burns the dung would need to buy not only fertilizer but also kerosene for lighting, whereas a family which composts the dung would need to buy all of its fuel and also some fertilizer, since bio-gas plants give a fertilizer richer in nitrogen than is obtained from composting.

Table 3 summarizes the economic analysis of the three alternatives. It shows that the cost of obtaining the same amounts of fuel and fertilizers is $\$ 31$ per yr for bio-gas plants as opposed to $\$ 34.8$ and $\$ 41.4$ for the options where dung is either burnt or composted. In these calculations, we have not taken into account the subsidy of $\$ 50$ given by the Indian Government for setting up a plant. The air pollutants contained in the smoke when dried dung, agricultural wastes and firewood are burnt are summarized in Table 4. The smoke also causes great discomfort to nose, lungs and eyes.'

(b) Impact of large-scale adoption

According to the 1961 census of the Government of India, twelve million rural households possess more than five animals. In terms of averages, these households have 7.5 members and possess 7.5 animals each. One may assume that, as a consequence of the fifty dollars subsidy and the low interest loan given by the Government of India to each household setting up a bio-gas plant, all these households will choose individual plants of an approximate capacity of $2.8 \mathrm{~m}^{3}$ each. With this assumption, we proceed to quantify the impact of this large-scale adoption.

Table 3. Economic analysis of alternatives for a private owner of five animals (dry dung $=3.65 \mathrm{t} / \mathrm{yr}$ ).

\begin{tabular}{|c|c|c|c|}
\hline Item & (A) & $\begin{array}{l}\text { Alternatives } \\
\text { (B) }\end{array}$ & (C) \\
\hline 1. Description of alternatives & $\begin{array}{l}\text { Install a } 1.8 \mathrm{~m}^{3} / \text { day bio-gas } \\
\text { plant and get fertiliser } \\
\text { and gas for cooking and } \\
\text { lighting }\end{array}$ & $\begin{array}{l}\text { Utilize the dung for burning } \\
\text { and purchase fertilizer } \\
\text { and kerosene for lighting }\end{array}$ & $\begin{array}{l}\text { Use dung for composting } \\
\text { and purchase fuels and } \\
\text { supplementary fertilizers }\end{array}$ \\
\hline 2. Investment (U.S. \$) & 200 & - & - \\
\hline $\begin{array}{l}\text { 3. Interest depreciation and } \\
\text { maintenance costs }(\$ / y r) \dagger\end{array}$ & 31 & - & - \\
\hline 4. Bio-gas generated $\left(\mathrm{m}^{3} / \mathrm{yr}\right)$ & 660 & - & - \\
\hline $\begin{array}{l}\text { 5. Effective heat obtained } \\
\left(10^{6} \mathrm{kcal} / \mathrm{yr}\right)\end{array}$ & 1.905 & 1.296 & - \\
\hline $\begin{array}{l}\text { 6. Fertilizer produced (kg } \\
\mathrm{N} / \mathrm{yr} \text { ) }\end{array}$ & 52.6 & - & 29.9 \\
\hline \multicolumn{4}{|l|}{ 7. Supplementary purchase } \\
\hline kerosene $(\mathrm{kg} / \mathrm{yr})$ & - & 25 & 25 \\
\hline dung cakes $(\mathrm{t} / \mathrm{yr})$ & - & 1.50 & 5.15 \\
\hline fertilizer (kg N/yr) & - & 52.6 & 22.7 \\
\hline 8. Annual costs\& & 31 & 34.8 & 41.4 \\
\hline
\end{tabular}

†Based on interest rate of $12 \%$, life of plant of $15 \mathrm{yr}$ and cost of painting the drum of $\$ 5$ per $\mathrm{yr}$.

(Annual capital charge $)=($ initial investment $) / \sum_{i=1}^{15} 1 /(1.12)^{r-1}$

$\ddagger$ Based on:

(i) Calorific value Efficiency of burning Effective calories

Dung $3100-3300 \mathrm{kcal} / \mathrm{kg} \quad 11 \% \quad 345-365 \mathrm{kcal} / \mathrm{kg}$

Bio-gas $4770 \mathrm{kcal} / \mathrm{m}^{3} \quad 60 \% \quad 2860 \mathrm{kcal} / \mathrm{m}^{3}$

(ii) Effective cooking energy needs amount to $1770 \times 10^{3} \mathrm{kcal} / \mathrm{yr}$ and can be obtained from either $615 \mathrm{~m}^{3}$ of bio-gas or 5.15 tons of dung cakes.

(iii) Either $25 \mathrm{~kg}$ of kerusene per yr or $46 \mathrm{~m}^{3}$ of bio-gas/yr are required for lighting.

(iv) $1 \mathrm{~kg}$ of dung when composted gives $0.56 \mathrm{~kg}$ of compost with $1.5 \%$ nitrogen. Through a bio-gas plant it yields $0.72 \mathrm{~kg}$ of dry sludge with $2.0 \%$ nitrogen.

$\$$ Based on prices of $\$ 0.12 / \mathrm{kg}$ of kerosene, $\$ 5.5 / \mathrm{ton}$ of dung cakes and $\$ 0.45 / \mathrm{kg}$ of nitrogen. 
Table 4. Estimated emissions of major pollutants from non-commercial sources (in kg per ton of fuel).

\begin{tabular}{lccc}
\hline & Firewood & Dry cattle dung & $\begin{array}{c}\text { Agricultural } \\
\text { waste products }\end{array}$ \\
\hline Carbon monoxide & 1.63 & 0.69 & 1.59 \\
Sulphur dioxide & 19.60 & 8.18 & 18.75 \\
Nitrogen oxides & 3.90 & 1.63 & 3.75 \\
Organics (including & & & \\
$\quad$ hydro carbons) & 23.50 & 9.81 & 22.05 \\
Particulates & 31.40 & 13.09 & 30.00 \\
Hydrogen sulphide & 1.20 & 0.45 & 1.12 \\
Ammonia & 1.20 & 0.45 & 1.12 \\
Hydrogen Chloride & 1.20 & $\underline{0.45}$ & 1.12 \\
& $\mathbf{8 3 . 6 3}$ & 34.77 & 79.40 \\
\hline
\end{tabular}

The commercial fuels and firewood saved by these families as a consequence of setting up the gas plants are summarized in Table 5. The data for energy consumption by these families have been obtained from a national sample survey carried out to assess rural household expenditures for fuel. ${ }^{10}$

At $\$ 250$ for a $2.8 \mathrm{~m}^{3}$ plant, $12 \mathrm{M}$ plants will cost $\$ 3000 \mathrm{M}$. The farmwaste and dung fed into these plants would be $65.7 \mathrm{M}$ tons per yr. The resulting savings of fuels amount to $0.43 \mathrm{M}$ tons of coal and coke, $24 \mathrm{M}$ tons of firewood, and $0.43 \mathrm{M}$ tons of kerosene. These fuels would be available for other purposes. These plants will also produce $7.4 \mathrm{M}$ tons of organic fertilizers having $0.148 \mathrm{M}$ tons of nitrogen from $10.3 \mathrm{M}$ tons of dung that would otherwise have been burnt. In addition, $52 \mathrm{M}$ tons of dung would also be fed into these plants, which would have been otherwise composted to obtain fertilizer. This would produce $0.728 \mathrm{M}$ tons of nitrogen. Thus, the total nitrogen is $0.876 \mathrm{M}$ tons. When valued for nitrogen content alone, this amounts to $450 \times 0.87 \times 10^{6}=\$ 400 \mathrm{M}$, without any foreign exchange requirement. It should be noted that our estimates of nitrogen obtained from these plants have been extremely conservative.

Here again many advantages are unquantified. Apart from the benefits of convenience and comfort of smokeless fuel, large-scale adoption can improve rural sanitation and help to avert deforestation.

Thus, it is seen that family plants are economical and the benefits, personal as well as national, are also not insignificant. They can meet the domestic energy needs of $90 \mathrm{M}$ people. This is, however, less than $\mathbf{2 0 \%}$ of the rural domestic energy needs. It will be shown in the next section that village level plants provide a much better alternative to family plants and can result in much greater benefits if the organizational aspects of operating such plants could be satisfactorily worked out.

\section{VILLAGE LEVEL PLANTS}

(a) Limitation of family plants and need for village level plants

In spite of personal gains and some national gains as well, the family plants are likely to have a limited impact for the following economic reasons.

(i) Only those $12 \mathrm{M}$ families having more than 5 (or at least 3 healthy) animals can install plants of adequate size and they must invest between $\$ 200$ and $\$ 250$ themselves and also maintain the plants. A large fraction of these families does not have so much capital. Even if all

Table 5. Fuel saved by installing 12 million family bio-gas plants of $2.8 \mathrm{~m}^{3}$ each to meet the fuel needs of $90 \mathrm{M}$ people.

\begin{tabular}{lccc}
\hline \multicolumn{1}{c}{ Fuel } & Unit & $\begin{array}{c}\text { Annual consumption } \\
\text { per person }\end{array}$ & $\begin{array}{c}\text { Annual consumption } \\
\text { for } 90 \text { M persons } \\
\text { in million tons }\end{array}$ \\
\hline Coke $(7500 \mathrm{kcal} / \mathrm{kg})$ & $\mathrm{kg}$ & 2.44 & 0.22 \\
Coal $(5000 \mathrm{kcal}, \mathbf{k g})$ & $\mathrm{kg}$ & 2.33 & 0.21 \\
Firewood $(4750 \mathrm{kcal} / \mathrm{kg})$ & $\mathbf{k g}$ & 269.00 & 24.20 \\
Kerosene & $\mathrm{kg}$ & 4.76 & 0.43 \\
Electricity & $\mathrm{kWh}$ & 0.61 & 0.055 \\
\hline
\end{tabular}


of the $12 \mathrm{M}$ households were to put up these plants, the direct benefits would be limited to less than $14 \%$ of the rural households.

In the suggested alternative, i.e. a larger, village-level plant, the farm waste from smaller holdings could also be involved, thus effectively utilizing most of the collectable farm waste of the village and minimizing inefficient use.

(ii) The size of a family plant is determined to provide enough gas to meet the family's needs even during the winter months when the production of gas is low. This is clear from Fig. $3,{ }^{1 "}$ which gives the monthwise output of gas per $\mathrm{kg}$ of dry dung. In the winter month of January, the yield is a minimum and is $0.17 \mathrm{~m}^{3}$, whereas in June the gas yield is $0.425 \mathrm{~m}^{3}$. The average output during the year is $0.31 \mathrm{~m}^{3}$. The family-size plants are designed to meet the need for the family at a production rate of $0.18 \mathrm{~m}^{3}$.

The gas generated in excess of $0.18 \mathrm{~m}^{3}$ is surplus for the family and if they do not have any seasonal use for it, this surplus would go to waste. In a village-level plant this gas could be given to other families.

(iii) Due to the larger size of a community plant, there would be an economy of scale in terms of land utilized, investment necessary and skilled man-hours required for operating and maintaining the plant. In fact, in the case of the family plant, in spite of the simple technology involved, the efforts required for its efficient operation may be beyond what a farmer can handle himself. Moreover, there is always some risk that a particular plant is not properly fabricated and a farmer may not want to invest, what is still a large sum for his family, on a separate plant but would prefer to pay the small deposit and rentals (for gas cylinders) required for getting gas from a community plant.

Clearly, village-level plants could have a much greater impact than the family-level plants. However, how does one make a community plant work? What kind of social management and organizational problems would be encountered? How does one collect farm waste and how does one distribute gas and fertilizers? How does one ensure cooperation from "rich" families who could set up their own plants and also involve poor families who spend hours in collecting fuel?

The scheme proposed below answers these questions; the economic viability of the suggested scheme is also examined.

\section{(b) Operating scheme for a village level plant}

The operating scheme proposed here is so designed as to ensure the cooperation of the top $14 \%$ families who own enough cattle to put up their own plants. By this scheme, they would be at least as well off by participating in the village-level plant as they would be if they were to set up their own plants. The poor who collect free dung from the streets would also be better off in this scheme.

Simply stated, the scheme is as follows. Dung is purchased daily for money. The fertilizer available is sold to the sellers of farmwaste at a fixed price with a limit in proportion to the farmwaste sold by them. Those who cannot affort to buy gas can come to the plant sites to cook their meals at a community kitchen that is attached to the community gas plant. They can do so in exchange for a few hours of service per week for the operation of the plant, such as collecting farmwaste or bringing water to the plant, maintaining cleanliness, etc., or for a price paid to utilize the burners for a certain time. One may even consider giving it free of cost if the situation permits and misuse is prevented. Cylinders and gas burners are rented out to users who would pay a deposit for these. There may be families too poor to be able to spare even a deposit of $\$ 20$ and for them community kitchens have to be provided.

We now examine the economic viability of such a scheme.

\section{(c) Guidelines for pricing policy}

Many efforts of taking technology to villages have failed in the past because the apparently "perfectly sensible" technologies do not take into account the immediate priorities and socio-economic conditions of the rural environment. It is difficult to sacrifice "a bit of the present" for a better future simply because the present conditions are already below satisfactory conditions of survival. For example, the introduction of smokeless "chulhas" (stoves 
made of earth) to save the poor from smoke have failed because these stoves consume more fuel and the poor prefer to put up with the smoke instead.

Therefore, special attention has been given here in evolving a pricing policy such that no one is worse off by the introduction of bio-gas plants. The participation of various income groups can be assured only by a "pareto superior" solution.

In fixing the prices of the various inputs and outputs, the following aspects should be kept in mind:

(i) Since selling of dung and buying of gas involves an extra effort for those who collect dung at present for consumption directly as fuel, the price at which dung is purchased by the plant should be a little higher than the present market price of dung. It may be mentioned here that such collecting systems already exist in India for various items, such as old newspapers, clothes, bottles and also a milk-collection system for co-operative dairies.

(ii) The price for a unit of gas should not exceed the price of an equivalent amount of delivered calories from an alternative source of fuel. Since $100 \mathrm{~m}^{3}$ of bio-gas delivers $286,000 \mathrm{kcal}$ and a ton of dung delivers $350,000 \mathrm{kcal}$, the price of $100 \mathrm{~m}^{3}$ bio-gas should not exceed the price of 0.817 ton of dung. Even though bio-gas is a much more convenient form of fuel and many would be willing to pay relatively more for it than for, say, dung cakes, this price limit has to be observed to ensure that even the poor are better off when using bio-gas rather than burning the dung directly.

(iii) The price of the fertilizer obtained from the plant has to be less than the price of equivalent nitrogen obtained from chemical sources. This puts an upper limit of $\$ 450 /$ ton of nitrogen.

(iv) The price charged for bio-gas should be such as not to cost the various rural households more than what they currently spend on fuel. The average expenditure for the rural cultivator household on energy was about $6 \%$ of its total consumer expenditure in 1971-72.

\section{(d) Benefit-cost analysis of village plant}

We assume a "typical" village community of 100 families ( 500 persons) and 250 animals, with 14 families possessing 5 or more animals. The price of cow dung cakes in the village is $\$ 55 /$ ton, i.e. $\$ 0.055 / \mathrm{kg}$ of dry dung. This should be the minimum purchase price of dung if the dung collectors are not to be worse off in selling their dung to the plant cooperative.

Some relevant characteristics of this community are described in Table 6 .

With $500 \mathrm{~kg}$ of dung, the gas production would vary from $85 \mathrm{~m}^{3}$ per day in winter to $221 \mathrm{~m}^{3} /$ day in summer and would amount, on the average to $157 \mathrm{~m}^{3} /$ day. With additional cellulosic wastes, the average generation can be considered to be $170 \mathrm{~m}^{3} / \mathrm{day}$. This will be adequate to meet the domestic fuel needs of the population of the village for all but the two or three winter months, when there will be a shortage of $20-40 \%$. However, in a community plant it may be possible to heat the plant in winter and not suffer a shortage of gas.

In fact, much greater design effort could be put in to increase efficiency and for monitoring the fermentation activities. The actual average gas production in this plant could be increased beyond $170 \mathrm{~m}^{3}$ per day.

We make the conservative assumption that 80 families will buy the gas in cylinders delivered to their homes. In addition, 20 families will come to the plant-site kitchen. We provide

Table 6. Characteristics of the typical village community.

\begin{tabular}{lc} 
(a) Population & 500 \\
(b) Families & 100 \\
(c) Number of Cattle and Buffalo (equivalent ${ }^{\dagger}$ adults) & 250 \\
(d) Families with 5 or more animals & 20 \\
(e) Dung collected (80\% of outturn) and potentially available for the community gas plant & $500 \mathrm{~kg} / \mathrm{day}$ \\
(f) Present domestic energy consumption per day: & \\
Coke and coal & $6.5 \mathrm{~kg}$ \\
Firewood & $367.7 \mathrm{~kg}$ \\
Dungcakes & $156.5 \mathrm{~kg}$ \\
Kerosene & $6.5 \mathrm{~kg}$ \\
Electricity $\ddagger$ & $0.83 \mathrm{kWh}$ \\
\hline
\end{tabular}

$\dagger$ In terms of dung production.

$\Varangle$ Most of the kerosene and electricity is used for lighting. 
YIELD

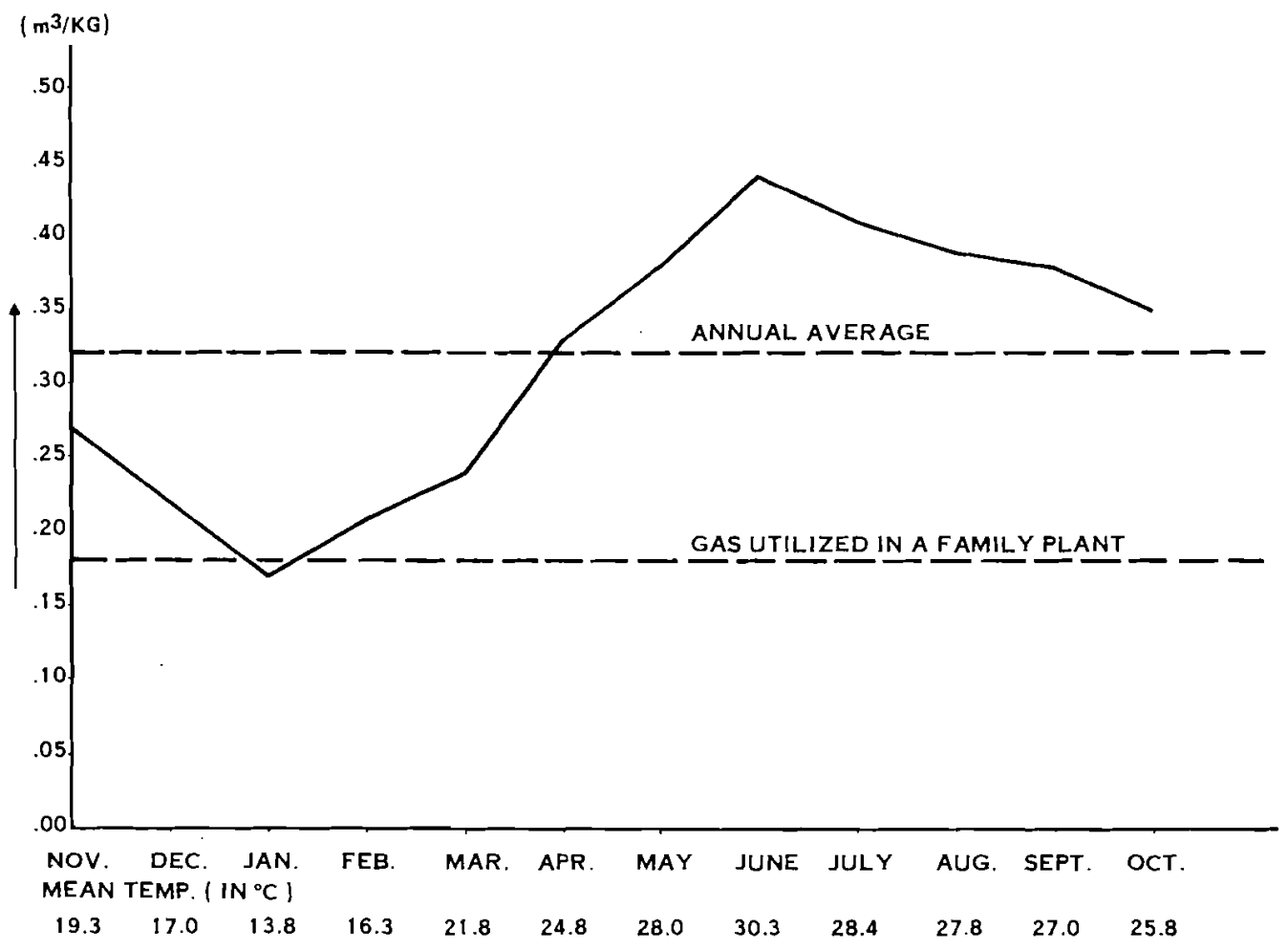

Fig. 3. Monthwise yield of bio-gas in $\mathrm{m}^{3} / \mathrm{kg}$ of dung.

for 10 sets of burners for these families. These many may not be necessary because some staggering in use may be easy to achieve.

With the above mentioned constraints in mind, we fix the price of dung at $\$ 6.0 /$ ton, the price of fertilizer at $\$ 250 /$ ton of $\mathrm{N}$ and the price of home-delivered bio-gas at $\$ 4.60 / 100 \mathrm{~m}^{3}$ and $\$ 3.5 / 100 \mathrm{~m}^{3}$ for gas used in the plant-site kitchen. The economics of the plant, based on these prices, are worked out in Table 7. It can be seen from this table that, given an interest rate of $12 \%$, the annual profits are more than adequate to recover the cost of the capital equipment in less than the $15 \mathrm{yr}$ (which is the life of the plant equipment). Thus, the suggested scheme is economically viable and it should be possible to operate a village-level plant commercially.

It should be noted that, at the proposed prices, all households are better off with the adoption of village bio-gas plants than otherwise. The poor family pays $\$ 21$ for fuel as compared to $\$ 25$ at present. The family having $10 \mathrm{~kg}$ of dung/day, i.e. enough to set up its own plant, pays $\$ 28.45$ for gas, $\$ 23.6$ for fertilizers and receives $\$ 22$ for sale of dung. Its net costs are thus $\$ 30.05 / \mathrm{yr}$, which is less than $\$ 31$ for installing its own plant (see Table 3). Moreover, the family is saved from the risks and trouble of installing and operating its own plant.

The advantages not quantified in the above analysis are summarized in Table 8 . The scheme, its operation and its impacts on various income groups are summarized in Figs. 4-6, respectively.

\section{(e) Potential and impact of large-scale adoption}

In order to get a quantitative assessment of the impact of large-scale adoption of bio-gas plants on the total energy scene in India, we look at the livestock position in the year 2000 , since the number of plants that can be put up depends on the expected animal population and the feeds available for this animal population. Between the 1965 and 1971 livestock censuses, the bovine animal population has not shown much increase. Thus, no substantial increase in animal population can be taken for granted. However, the availability of dung depends on the weight and the feed of animals. ${ }^{8}$ If the cattle population in the year 2000 is assumed to remain at its current level of $200 \mathrm{M}$ equivalent adult bovine heads in rural India, they should certainly be well fed as more roughages (cattlefeed) would be available due to additional food-grain 
Table 7. Economics of a village level plant of $170 \mathrm{~m}^{3}$ of gas/day capacity.

\begin{tabular}{lr}
\hline Costs: & U.S.\$ \\
A. Investment & \\
(a) Plant of $170 \mathrm{~m}^{3} /$ day capacity & 4000 \\
(b) Plant-site kitchens & 500 \\
(c) Plant-site washing facilities & 200 \\
(d) Compressor & 300 \\
(e) 250 Cylinders & 2500 \\
(f) 100 Burners & 1000 \\
(g) Delivery carts & 500 \\
(h) Land and preparation for drying beds & 1000 \\
$\quad$ Total investment costs & 10,000 \\
B. Operating Costs per annum & \\
(a) Purchase of dung, & \\
$500 \mathrm{~kg}$ at $\$ 6.0 /$ ton per day (6.0 $\times 365) / 2=$ & \\
(b) Plant and compressor maintenance & 1100 \\
(c) Staff & 400 \\
(i) Manager/Accountant & \\
(ii) Dung Collection and Feeding & \\
(iii) Gas Distribution & \\
(iv) Water Procurement & \\
(v) Kitchen Maintenance & \\
(d) Total operating costs & 2500 \\
C. Receipts per annum & \\
(a) Sale of Gas & \\
$49,500 \mathrm{~m}^{3}$ of bottled gas at $\$ 4.60 / 100 \mathrm{~m}^{3}$ & \\
$12,600 \mathrm{~m}^{3}$ of gas at $\$ 3.5 / 100 \mathrm{~m}^{3}$ & 1180 \\
(b) Sale of fertilizer: 2.63 ton of $\mathrm{N}$ at $\$ 450 /$ ton & 1395 \\
D. Gross Annual Earnings (Receipts—Operating Costs) & \\
\hline
\end{tabular}

Table 8. Advantages not quantified.

(a) Individual:

(i) Convenience of fuel which can be turned on and off at any time.

(ii) Elimination of smoke discomfort and its adverse health effects.

(iii) No need for private maintenance and private investments.

(b) National:
(i) Availability of commercial fuels for industrial uses.
(ii) Savings in investment and foreign exchange used for chemical fertilizer.
(iii) Aid to prevention of deforestation and all its consequences such as soil erosion, floods and climatic effects.
(iv) Improved rural sanitation due to collection of dung and burning of night soil through attached latrines.
(v) Reduced air pollution.
(vi) Reduced health care budget as a consequence of
(a) reduction in water-borne diseases caused by lack of sewage and sanitation;
(b) reduction in the presence of smoke in households causing lung and eye disease.
(vii) Creation of employment in rural areas and saving of man-hours spent in gathering fuel.

(c) Other:

(i) Does not consider the possibility of additional gas output using as input agricultural waste, which is burnt at present. The addition of night soil, poultry and piggery waste is also not considered. These have higher rates of gas production than cattle dung.

(ii) Assumes conservative figures for the availability of dung and does not take into account the likely future escalation of prices of commercial fuels and chemical fertilizers.

(iii) Does not consider improvement in gas production (by the bio-gas plant) due to technological advances. Better knowledge of fermentation processes could increase production by a large factor.

production required for the larger human population. Thus, the availability of dung can be taken to be twice the availability of dung today. The $200 \mathrm{M}$ well-fed bovine animals should be able to support $200 \times 2 / 250=1.60 \mathrm{M}$ community plants. $1.60 \mathrm{M}$ such plants would provide energy equivalent to $67 \mathrm{mtce}$ and can meet $90 \%$ of the domestic needs of the projected $660 \mathrm{M}$ rural population in the year 2000 at the present level of per capita energy consumption.

Two possible scenarios of rural domestic energy supply in $2000 \mathrm{AD}$ are shown in Table 9 . From this table, it is possible to compare the scenario depicting a coal-based strategy with the scenario depicting the bio-gas strategy. Thus, we see that through the latter strategy, $100 \times$ 


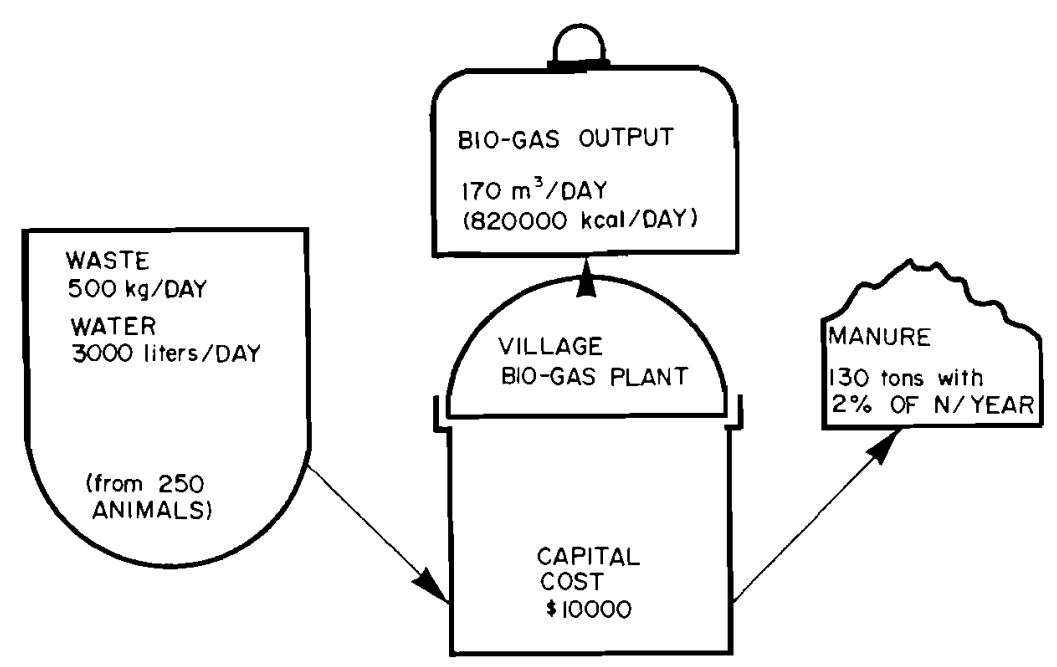

Fig. 4. Schematic diagram of a village bio-gas plant.

Quantified benefits per capita:

1. Availability of $6 \times 10^{6} \mathrm{kcal} / \mathrm{yr}$ of energy in a convenient form

2. Availability of $5.2 \mathrm{~kg}$ of nitrogen per year and consequently $52 \mathrm{~kg}$ of additional foodgrains per yr.

Per capita costs:

1. Initial investment of $\$ 20$.

2. Annual maintenance cost of $\$ 7$.

Village level benefits in general terms:

1. Domestic energy needs of 500 persons met.

2. Prevention of deforestation.

3. A smokeless fuel for all.

4. Improvement in sanitation, cleanliness and health

5. At least 10 tons of additional foodgrains per $\mathrm{yr}$.

6. Only local renewable sources required.

7. A more efficient and versatile fuel is produced.

\begin{tabular}{|l|}
\hline OBJECTIVE \\
O. ENSURE \\
PARTICIPATION OF \\
ALL INCOME \\
GROUPS \\
\\
\\
b. PROFITABLE \\
OPERATIONS \\
\hline
\end{tabular}

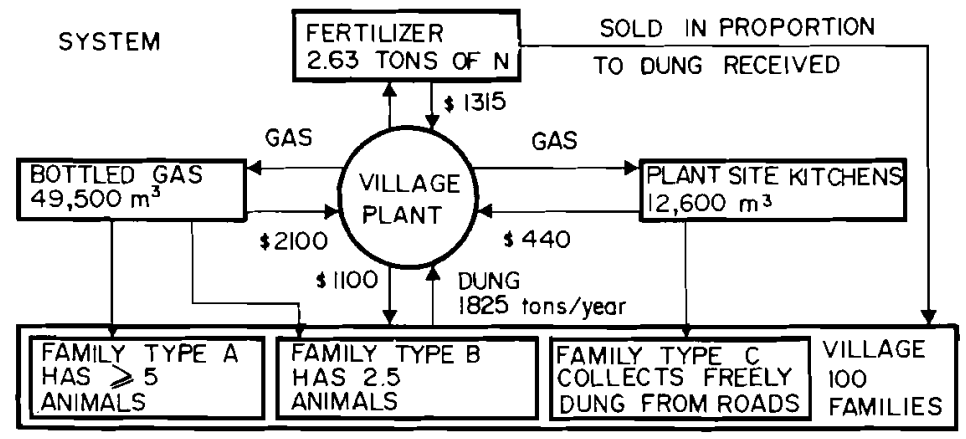

Fig. 5. Operating system for a village plant.

\begin{tabular}{|c|c|c|c|c|}
\hline & $\begin{array}{c}\text { FAMILY TYPE A } \\
\text { (HAS } \geqslant 5 \text { ANIMALS) } \\
\end{array}$ & $\begin{array}{l}\text { FAMILY TYPE B } \\
\text { (HAS } 2.5 \text { ANIMALS) }\end{array}$ & $\begin{array}{c}\text { FAMILY TYPE C } \\
\text { (COLLECTS DUNG FROM } \\
\text { ROADS FOR FREE) } \\
\end{array}$ & $\begin{array}{l}\text { VILLAGE } \\
100 \\
\text { FAMILIES }\end{array}$ \\
\hline IMPACT & $\begin{array}{l}\text { PAYS } \\
\$ 28.45 \text { FOR GAS } \\
\$ 23.60 \text { FOR N } \\
\text { RECEIVES } \\
\$ 22.00 \text { FOR DUNG }\end{array}$ & $\begin{array}{l}\text { PAYS } \\
\$ 28.45 \text { FOR GAS } \\
\$ 8.40 \text { FORGONE } \\
\text { EARNINGS FROM } \\
\text { COMPOST } \\
\text { RECEIVES } \\
\$ 11.00 \text { FOR DUNG }\end{array}$ & $\begin{array}{l}\text { PAYS } \\
\$ 21.00 \text { FOR } \\
\text { COOKING } \\
\text { RECEIVES } \\
\$ 22.00 \text { FOR DUNG }\end{array}$ & \\
\hline RESULT & $\begin{array}{l}\text { CHEAPER THAN } \\
\text { OWN BIO-GAS } \\
\text { PLANT }\end{array}$ & $\begin{array}{l}\text { FUEL COST } \\
\text { LESS THAN PRESENT } \\
\text { EXPENDITURE OF } \$ 25\end{array}$ & $\begin{array}{l}\text { BETTER TO SELL } \\
\text { DUNG THAN TO } \\
\text { BURN IT }\end{array}$ & \\
\hline
\end{tabular}

Fig. 6. Impacts of a village plant on various income groups. 
Table 9. Alternative scenarios of energy supply for the Indian rural household sector in $2000 \mathrm{AD}$.

\begin{tabular}{|c|c|c|}
\hline \multicolumn{2}{|c|}{$\begin{array}{l}\text { 1. Rural population } \\
\text { 2. Domestic energy requirement per person at the } \\
\text { present consumption level }\end{array}$} & $\begin{array}{c}660 \text { millions } \\
0.27 \text { ton of coal per yr }\end{array}$ \\
\hline Fuels & $\begin{array}{c}\text { Scenario } 1 \\
\text { Coal based strategy }\end{array}$ & $\begin{array}{c}\text { Scenario } 2 \\
1.6 \times 10^{6} \text { village level } \\
\text { bio-gas plants }\end{array}$ \\
\hline $\begin{array}{l}\text { (a) coal }(7000 \mathrm{kcal} / \mathrm{kg}) \\
\text { (b) Kerosene } \\
\text { (c) Bio-gas }\end{array}$ & $\begin{array}{l}164 \times 10^{6} \text { tons } \\
3.5 \times 10^{6} \text { tons } \\
-\end{array}$ & $\begin{array}{l}10 \times 10^{6} \text { tons } \\
1.5 \times 10^{6} \text { tons } \\
100 \times 10^{9} \mathrm{~m}^{3}\end{array}$ \\
\hline
\end{tabular}

$10^{9} \mathrm{~m}^{3}$ of bio-gas produced by $1.6 \mathrm{M}$ plants can replace $154 \mathrm{M}$ tons of coal and $2 \mathrm{M}$ tons of kerosene, even though, in coal-equivalent terms, this much bio-gas amounts to only $67 \mathrm{M}$ tons because bio-gas burns with a much greater efficiency than coal in the stoves used by the rural households in India. When the different efficiencies are taken into account, $100 \times 10^{9} \mathrm{~m}^{3}$ of bio-gas provide as much energy as $165 \mathrm{M}$ tons of coal. The importance of taking the efficiencies (of use) of different fuels into account, especially when dealing with rural household-energy consumption, is well recognized in India, where it is customary to use coal replacement rather than coal equivalent units in energy studies. Indian coal is of poor quality having only $5000 \mathrm{kcal}$ per $\mathrm{kg} ; 165 \mathrm{M}$ tons of US coal with $7000 \mathrm{kcal} / \mathrm{kg}$ is equivalent to about $230 \mathrm{M}$ tons of Indian coal.

Each of the plants will also produce fertilizer with 2.63 tons of nitrogen per year. Thus, $1.60 \mathrm{M}$ plants will produce $4.2 \mathrm{M}$ tons of nitrogen per yr.

It should be noted that, in 1973 , only $1.85 \mathrm{M}$ tons of nitrogen was applied through chemical fertilizers on the $165 \mathrm{M}$ hectares of gross cropped areas in India. The average fertilizer input per hectare was thus $11 \mathrm{~kg}$. A village bio-gas plant provides 130 tons of manure containing 2.6 tons of nitrogen. A village of 500 persons would have 175 hectares of cropped land and the nitrogen from bio-gas plants would amount to $15 \mathrm{~kg}$ per hectare every year. At least half of this nitrogen is in addition to what would have been possible to obtain through conventional composting.

The total investment required will be $\$ 10000 \times 1.60 \times 10^{6}=\$ 16 \times 10^{9}$; this also includes the cost of burners, plant-site kitchens and other facilities for the households. If the bio-gas option is not pursued, that much coal will have to be provided every year instead. Coal is a non-renewable resource and its price would go on increasing with continued use. The investment cost in developing the necessary coal mines and the railway system capable of transporting $230 \mathrm{M}$ tons of coal is estimated ${ }^{12}$ to be $\$ 9.5 \times 10^{9}$. This has to be compared with the $\$ 16 \times 10^{9}$ investment required for the bio-gas plants. However, while the main cost of the bio-gas scheme is the initial investment cost, for coal mining the capital cost is just one part of the final cost of coal and substantial operating costs of mining and transport will be incurred each year. Thus, the total cost of energy from coal would be much higher than that from bio-gas.

The supply scenario with bio-gas plants described above should be attainable since gas is a convenient and preferred cooking fuel. No difficulties of market penetration should arise.

Depending on the growth of the economy, the total energy consumption in India is likely to grow at an annual rate of 5 to $6 \%$ until $2000 \mathrm{AD}$. On this basis, the contribution of bio-gas energy would be between 10 and $15 \%$ of the total energy use in the country. Though not insignificant, the impact of bio-gas energy from our calculations is modest compared to that shown by Prasad et $a l^{7}$ who suggest that the total rural energy requirements (i.e. domestic, agricultural and industrial requirements) can be met entirely by village bio-gas plants. Their estimates of rural energy needs are extremely low. The estimates of domestic energy needs used by us are consistent with the various systematic sample surveys carried out in India.

\section{BIO-GAS PLANTS FOR SANITATION IN SLUMS}

An essential measure for slum improvement is the provision of clean water and sanitary facilities. Paucity of resources usually precludes providing every family with a private water tap and a latrine. Public water taps and latrines are usually built to be shared by a number of 
families. Unfortunately, these public facilities are seldom kept clean and usually become a source of nuisance rather than an improvement in the environment of the slum.

Unless some private vested interest is created in maintenance, cleanliness is not likely to be achieved. Imposing a service charge for using clean public toilets is not possible in India and certainly not in the slums where people would not use the facilities rather than pay money for its use.

In a slum area, we propose to set up a cluster of public latrines and attached to a bio-gas plant. The right to the products of the plant, namely gas and fertilizer, are transferred along with the responsibility of maintaining the cleanliness of the latrines to someone in the slum.

If this plant is connected to a cluster of 5 latrines and if 20 families were to use these latrines, $8.5-11.3 \mathrm{~m}^{3}$ of gas per day would be produced, which should be adequate for four families. Thus the "supervisor" can sell the gas to three other families. The cooking-fuel expenditure for coal or dung cakes or wood for an urban family would be about $\$ 2.5$ per month and thus it should be willing to spend at least that much for bio-gas, a superior and more convenient cooking fuel.

The amount of fertilizer obtained from one plant used by 100 persons would be more than $300 \mathrm{~kg}$ of nitrogen per yr. This should have a sale value of $\$ 120$. Thus, the supervisor's income would be $\$ 240 / y r$, including the value of gas consumed by him. This should be a sufficient incentive for him to keep his cluster of latrines clean as this is higher than the average GNP per capita $(\$ 100)$ and as this does not demand more than a few hours of work a day. Preferably, in the same slum, two or three such clusters should be created in order to introduce an element of competition. In bigger slums, more latrines can be attached to derive benefits from economies of scale.

The cost of an $8.5 \mathrm{~m}^{3}$ bio-gas plant along with the associated pipe connections would be around $\$ 700$. With this expenditure, the state saves on costs of sewage and gains products worth $\$ 240$ every year.

\section{BIO-GAS PLANTS IN OTHER COUNTRIES}

\section{(a) Scope in developing countries}

There are a number of developing countries, especially in Asia and Africa, which have neither coal nor oil resources and which depend largely on imports for meeting their energy needs or on their forest or treeland reserves and on agricultural waste. Table 10 gives data about some such developing countries. It should be noted that, due to the inefficiency of burning firewood, the effective energy delivered from wood may not be as high as the coal equivalert number implies.

This is not an exhaustive but only an illustrative list. Many countries with a population of less than $5 \mathrm{M}$ are not included here. Besides, some countries like Bangladesh, Pakistan and India may have some energy resources but the present production is not adequate to meet even

Table 10. Data about some countries which have no (or negligible) production of commercial energy.

\begin{tabular}{|c|c|c|c|c|}
\hline & $\begin{array}{l}\text { Commercial } \ddagger \text { energy } \\
\text { consumption } \\
\text { per capita } \\
\text { in kgce } \ddagger\end{array}$ & $\begin{array}{l}\text { Fuel woodई } \\
\text { consumption } \\
\text { per capita } \\
\text { in kgce }\end{array}$ & $\begin{array}{l}\text { GNP/capita§ } \\
\text { (U.S. } \$ \text { ) }\end{array}$ & $\begin{array}{l}\text { Populationf } \\
\text { in millions }\end{array}$ \\
\hline Kenya & 167 & 384 & 143 & 12.0 \\
\hline Sudan & 123 & 495 & 117 & 17.4 \\
\hline Tanzania & 81 & 958 & 100 & 14.3 \\
\hline Uganda & 56 & 635 & 135 & 9.3 \\
\hline Mozambique & 243 & 434 & 240 & 8.2 \\
\hline Ghana & 175 & 361 & 256 & 10.0 \\
\hline Guatemala & 277 & 482 & 367 & 5.6 \\
\hline Nepal & 13 & 315 & 85 & 12.0 \\
\hline Sri Lanka & 147 & 132 & 174 & 13.5 \\
\hline Thailand & 319 & 164 & 190 & 40.0 \\
\hline Philippines & 304 & 218 & 259 & 42.0 \\
\hline
\end{tabular}

łkgce = kilogram of coal equivalent;

‡rom World Energy Supplies, U.N. (1973);

§from Production Yearbook, FAO (1973);

fthe figures are for 1970 from the Yearbook of National Accounts Statistics (1973). 
Table 11. US Waste: quantities discarded (in millions of combustible dry tons).

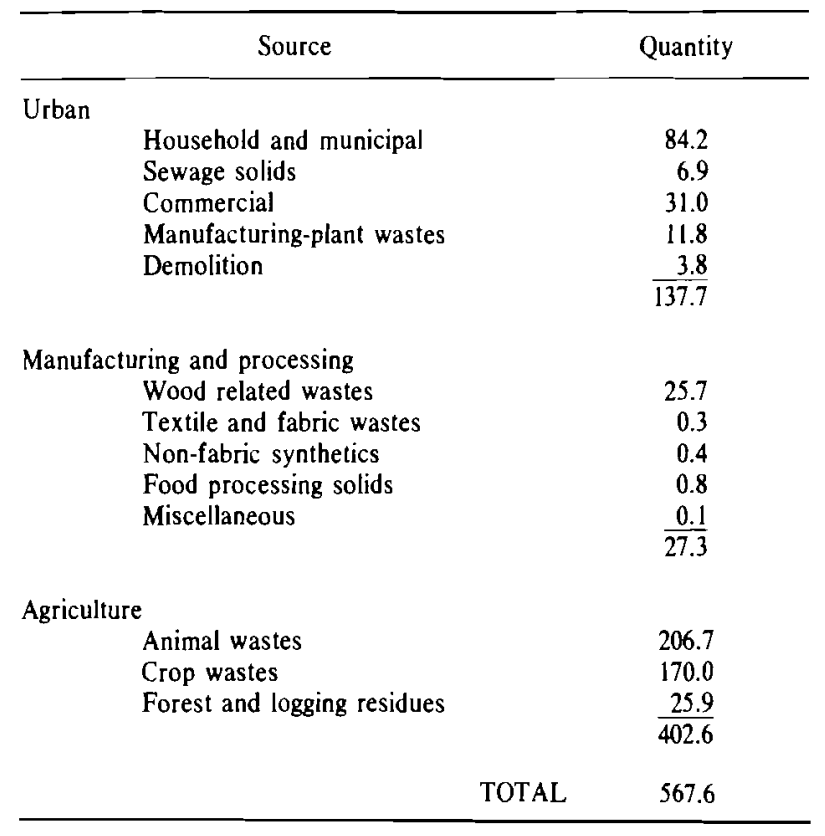

Source: International Research and Technology Corp., USA (1976).

$50 \%$ of their total energy demand. In India's case, fuel-wood consumption is $80 \mathrm{~kg}$ per person. Considering India's massive population, even this low consumption puts pressure on the forests. The same may hold for Thailand and the Philippines. Since the GNP per capita is also low in these countries, the rising oil prices may demand an excessively large portion of foreign exchange earnings.

China has been utilizing nightsoil and waste from piggeries for a long time. Recently, South Korea, Thailand and other South-East Asian countries have also stepped up their efforts in introducing bio-gas plants. However, by and large, the practice of burning dung remains quite prevalent in many developing countries, especially in the Far East.

\section{(b) Bio-gas plants in a developed economy}

Perhaps one country which can effectively go in for bio-gas plants is the U.S., which is at the other extreme of economic development. The cattle population in the U.S. ranks second in the world and the output of U.S. cattle from all points of view is several times that of cattle in India, as was shown in Table 1.

Table 11, which gives the waste distribution in the US, shows that in quantity its $400 \mathrm{M}$ tons of agricultural waste ranks first and is $70 \%$ of the total waste, with urban waste trailing second. In this context, the sheer magnitude of the problem of waste disposal, which could give rise to severe environmental problems, may prompt the US to consider bio-gas plants as an option for waste disposal while getting valuable by-products, i.e. gas and fertilizer. Since the animals are often stall-fed at a given place, the collection operation is likely to be much simpler and could be handled mechanically.

Acknowledgements-The authors are grateful to Dr. W. Sassin and Sudhakar Rao for their constructive comments. Thanks are also due to Lilo Roggenland for her unfailing readiness to type the various drafts of this paper.

\section{REFERENCES}

1. United Nations, World Energy Supplies 1970-73, Statistical Papers, Series J, No. 18, New York, 1975.

2. Government of India, Report of the Fuel Policy Commitree, New Delhi, 1975.

3. Government of India, Draft Fifth Five Year Plan, Planning Commission, New Delhi, 1973.

4. Government of India, Indian Livestock Census, 1966, New Delhi.

5. National Council of Applied Economic Research, Domestic Fuels in India. Asia Publishing House, New Delhi (1959).

6. Khadi and Village Industries Commission, Gobar gas: why and how. Jan. 1974, New Delhi.

7. C. R. Prasad, K. K. Prasad and A. K. N. Reddy, Bio-gas plants: prospects, problems and tasks. Econ. Polit. Weekly IX, 32-34, Special number, Bombay, Aug. 1974. 
8. K. S. Parikh, Benefit-cost analysis Department of bio-gas plants in India. M.Sc. Thesis, Massachusetts Institute of Technology, Cambridge, Mass., 1963.

9. J. K. Parikh, Environmental problems of India and their trends in future. Department of Science and Technology, Government of India, New Delhi, 1976.

10. Government of India, National sample survey, 18 Feb. 1963 to Jan. 1964, Report No. 141, New Delhi.

11. C. N. Acharya, Preparation of fuel gas and manure by anaerobic fermentation of organic materials. Indian Council of Agriculture Research, Research Series No. 15, New Delhi, 1957.

12. K. S. Parikh, Second India Studies: Energy. Macmillan, New Delhi (1976). 